\title{
Studies on Effect of Slice Thickness and Temperature on Drying Kinetics of Kothimbda (Cucumis Callosus) and its Storage
}

Gojiya DK* and Vyas DM

Department of Processing and Food Engineering, College of Agricultural Engineering and Technology, Junagadh Agriculture University, Junagadh, Gujarat (362001), India

\begin{abstract}
Cucumis callosus (Rottl.) Cogn (Cucurbitaceae) is very common throughout the India and commonly known as "Kothimbda" in Gujarat. Kothimbda is rich source of vitamin C $(19.99 \mathrm{mg} / 100 \mathrm{~g})$ to human beings. The Kothimbda slice was dried in Industrial tray dryer with three levels of drying temperature $\left(50,60\right.$ and $\left.70^{\circ} \mathrm{C}\right)$ with constant air velocity at $1.5 \mathrm{~m} / \mathrm{sec}$ and in solar cabinet dryer also with three levels of thickness $(3 \mathrm{~mm}, 5 \mathrm{~mm}$ and $7 \mathrm{~mm}$ ). The observations on reduction in weight were taken regularly with increase in time and were evaluated in terms of drying characteristics. Three drying models i.e. Page, Henderson and Pabis and Logarithmic were tested for their validity. The values of coefficient of determination $\left(r^{2}\right)$ for all the three models under all the treatments were found to be above 0.9 , suggesting good fit of the observations. Though, the value of $r^{2}$ under the Logarithmic Model was more followed by page and Henderson and Pabis, indicating the Logarithmic model more reliable for prediction and found best fitted. The temperature and slice thickness affected significantly on the ascorbic acid content during drying of Kothimbda slice. During storage observations in terms of ascorbic acid were recorded at 15 days interval. The ascorbic acid content of the stored dried Kothimbda powder was decreasing with the increase in storage period under room temperature storage. The loss in ascorbic acid during storage was minimum in the powder packed in Glass bottle followed by HDPE bag and Aluminum Coated P.P. bag.
\end{abstract}

Keywords: Kothimbda; Drying; Thickness; Packaging; Ascorbic acid; Temperature

\section{Introduction}

Cucumis callosus (Rottl.) Cogn (Cucurbitaceae) is very common throughout the India and commonly known as "Kothimbda" in Gujarat. The mature fruits of Cucumis callosus (rottl.) Cogn (Kothimbda), a drought tolerant cucurbitaceous vegetable found growing abundantly during rainy season in the arid and semiarid regions of North-Western India, particularly in Gujarat and Rajasthan, are usually cooked with various vegetable preparations. It is an ideal summer vegetable crop chiefly grown for its edible tender fruits, preferred as salad ingredient, pickles, Desert fruit and as a cooked vegetable. The ripe fruits are eaten as such, while unripe fruits used as vegetable. Fruits are known to contain vitamin $\mathrm{C}[1]$.

Kothimbda powder obtained after drying the fruits is used as souring agent in combination with other spices to make spice premix and mouth fresheners. Powder of Kothimbda with other spices is commonly used for various therapeutic purposes to cure stomach pain, nausea, vomiting and constipation. The dehydrated Kothimbda is coughicide, vermicide, cooling, diuretic and gastric stimulant. Amongst all nutrients Ascorbic acid (Vitamin C) is most important from the processing point of view [2].

The post-harvest loss of Kothimbda varies from 30 to 40 per cent due to its perishable nature and glut during harvesting time, which also reduces the market value of the fruit. Hence, dehydration is the only solution to overcome the problem of post-harvest losses as well as to provide high returns to the growers along with the availability of the fruit during off season. The farmers producing Kothimbda of our country are still using the traditional drying techniques for drying of Kothimbda and so far very little scientific research work has been undertaken on standardization of drying and dehydration technology especially for Kothimbda. Appropriate size of slices and drying temperatures are good for drying and improve the appearance, colour and quality of dehydrated product.

Generally, fruits and vegetables are heat sensitive and therefore present a special problem when drying. Dehydration has to be carried out under carefully controlled conditions. Sun drying is being increasingly adopted in vegetable preservation due to high cost skill required in the artificial drying method. Though, conservation of nutrients is very important in view of the prevalent micronutrient deficiency problems. The action of applying heat to a material in order to dry it does not merely remove the moisture but can also affect the nutritional qualities of the dried product [3]. The rate of drying depends upon the rate of humidity and size or thickness of the pieces. The range of drying is determined by a range of factors such as external air, temperature, the size of the food pieces been dried and the depth to which the drying tray is packed. Since these factors vary, it is impossible to give an exact drying time for any particular food item. Considering all above aspects in mind a study was undertaken to quantify the losses in those quality parameters during drying and establish appropriate drying temperature and time that will result in optimum retention of the nutritional parameters as well as ensuring storage stability.

\section{Materials and Methods}

For this experimentation mature, the sound and uniformly matured fruits without any damage were selected for the experiment and washed in tap water. The washed and shade dried Kothimbda fruits were sliced into $3 \mathrm{~mm}, 5 \mathrm{~mm}$ and $7 \mathrm{~mm}$ thickness by using stainless steel knife. To prevent bacterial and mold infection, knifes

*Corresonding author: Devanand Karabhai Gojiya, Department of Processing and Food Engineering, College of Agricultural Engineering and Technology, Junagadh Agriculture University, Junagadh, Gujarat (362001), India, Tel: +919537567444; E-mail: dkgojiya@gmail.com

Received October 12, 2014; Accepted November 14, 2014; Published January 07, 2015

Citation: Gojiya DK, Vyas DM (2015) Studies on Effect of Slice Thickness and Temperature on Drying Kinetics of Kothimbda (Cucumis Callosus) and its Storage. J Food Process Technol 6: 406. doi:10.4172/2157-7110.1000406

Copyright: ( 2015 Gojiya DK, et al. This is an open-access article distributed under the terms of the Creative Commons Attribution License, which permits unrestricted use, distribution, and reproduction in any medium, provided the original author and source are credited. 
were frequently dipped into potassium permanganate solution (5\%) for 2 minutes before reusing for slicing. The slices of Kothimbda Slices were uniformly spread in single layer in tray for dehydration. The dried Kothimbda slices were grinded into the desired particles sizes by the Bajaj make grinder of $600 \mathrm{~W}$ and $1800 \mathrm{rpm}$. The powder of dried Kothimbda slices obtained under different was sieved with the help of IS Sieves, having openings of size ( 16 mesh) to obtained the of uniform desired particle size of 16 mesh.

The packaging of Kothimbda powder of each treatment under study was done in glass bottles, Polyethylene pouches of $300 \mu$ thickness and in Aluminum coated P.P. bags. All the containers were stored for a period of 3 months at room temperature. Temperature and relative humidity during the storage period was varying between 7.4 to $36.5^{\circ} \mathrm{C}$ and 13 to 95\% respectively. The observations in terms of Ascorbic Acid content were recorded at an interval of 15 days besides initially during storage. To estimate ascorbic acid content, the following procedure as reported by Sadasivam and Manikam [4] will be followed. The experiment was carried out in a Factorial Completely Randomized Design (F-CRD) with three factors and two replications for the study of effect of slice thickness, temperature and Packaging materials on storage.

\section{Results and Discussion}

It was observed that, one of the main factors influencing the drying kinetics of the product during the falling rate drying period is the drying air temperature. The results showed that the increase in drying air temperature resulted in a decrease in the drying time (Figures 1-4). It also showed that drying time increased with increasing thickness of Kothimbda slices. The drying rate reached its maximum values at higher drying air temperatures. It is decreased continuously with decreasing moisture content or improving drying time. The moisture removal inside the Kothimbda slices were higher at higher drying air temperatures, because the migration of moisture to the surface and the evaporation rate from surface to air slows down with decreasing the moisture in the product, the drying rate clearly decrease (Figures 1-4). While the mean drying rate was $3.36 \mathrm{~g}, 4.12 \mathrm{~g}, 4.87 \mathrm{~g}$ and $1.46 \mathrm{~g}$ water per g dry matter per hour at a drying air temperature of $50^{\circ} \mathrm{C}, 60^{\circ} \mathrm{C}$, $70^{\circ} \mathrm{C}$ and solar drying respectively at a velocity of $1.5 \mathrm{~m} / \mathrm{s}$ for $3 \mathrm{~mm}$ thickness, $4.11 \mathrm{~g}, 4.82 \mathrm{~g}, 5.66 \mathrm{~g}$ and $1.18 \mathrm{~g}$ water per $\mathrm{g}$ dry matter per hour at a drying air temperature of $50^{\circ} \mathrm{C}, 60^{\circ} \mathrm{C}, 70^{\circ} \mathrm{C}$ and solar drying respectively for $5 \mathrm{~mm}$ thickness and $4.79 \mathrm{~g}, 4.31 \mathrm{~g}, 3.38 \mathrm{~g}$ and $1.09 \mathrm{~g}$ water per g dry matter per hour at a drying air temperature of $50^{\circ} \mathrm{C}$, $60^{\circ} \mathrm{C}, 70^{\circ} \mathrm{C}$ and solar drying respectively for $7 \mathrm{~mm}$ thickness. Similar results are reported by Kabiru et al. [5] for drying of mango slice, Islam et al. [6] for green banana, Limpaiboon [7] in case of pumpkin slice and Abano et al. [8] for drying of tomato slices.

The observations taken during all the drying treatments were fitted to Henderson and Pabis, Page and Logarithmic model and the predicted equations were also determined (Figures 5-16). The values of coefficient of determination $\left(r^{2}\right)$ for all the three models under all the treatments were found to be above 0.9, suggesting good fit of the observations. Though, the value of $\mathrm{R}^{2}$ under the Logarithmic Model was more followed by page and Henderson [9] and Pabis, indicating the Logarithmic model more reliable for prediction and found best fitted. The values of constants of different models are given in Table 1.

\section{Effects of different temperature and thickness levels on ascorbic acid during drying}

The ascorbic acid of fresh Kothimbda fruits was found as 19.99 $\mathrm{mg} / 100 \mathrm{gm}$ of pulp. The highest value of ascorbic acid was found as
$45 \mathrm{~g} / 100 \mathrm{~g}$ for the samples dried with $50^{\circ} \mathrm{C}$ temperature and $7 \mathrm{~mm}$ thickness. While, the lowest value was found as $31.66 \mathrm{~g} / 100 \mathrm{~g}$ for solar dried samples with $5 \mathrm{~mm}$ thickness (Table 2). The various statistical characters were calculated through statistical analysis of observations on ascorbic acid content of powder samples. The values of mean, standard error of mean, critical difference and coefficient of variance obtained are given in Table 2. From the table it is clear that the temperature and slice thickness affected significantly the ascorbic acid content during drying of Kothimbda .

The highest ascorbic acid content was found in the powder prepared from slices of $7 \mathrm{~mm}$ thickness and dried at $50^{\circ} \mathrm{C}$ temperature.

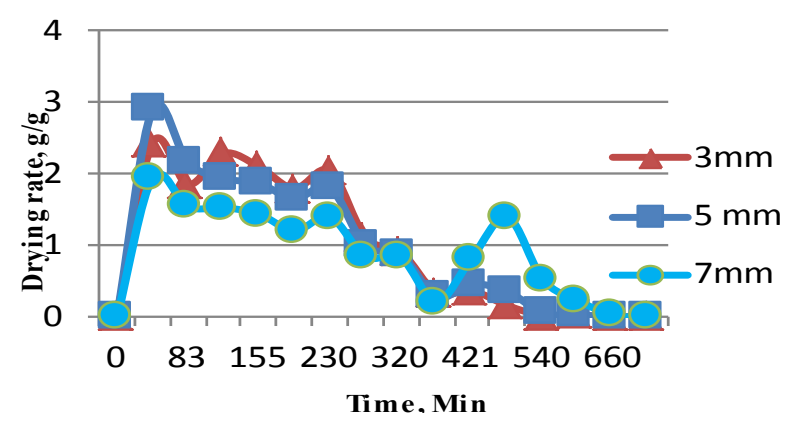

Figure 1: Variation in drying rate with time $\left(50^{\circ} \mathrm{C}\right.$ Air temperature)

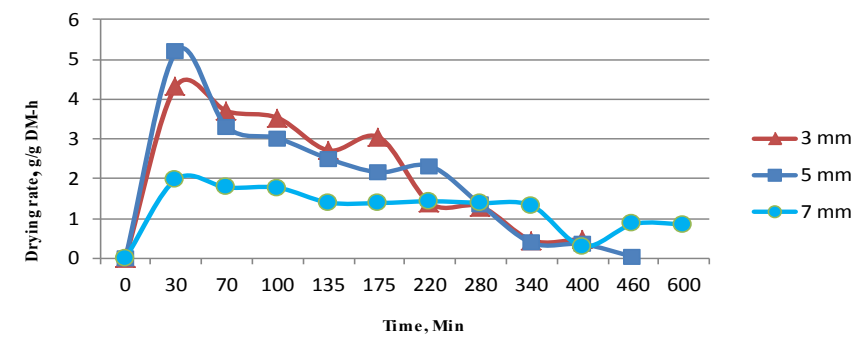

Figure 2: Variation in drying rate with time $\left(60^{\circ} \mathrm{C}\right.$ Air temperature)

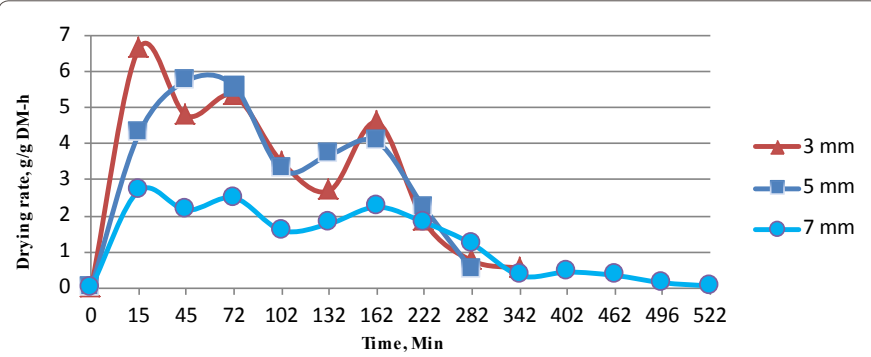

Figure 3: Variation in drying rate with time $\left(70^{\circ} \mathrm{C}\right.$ Air temperature)

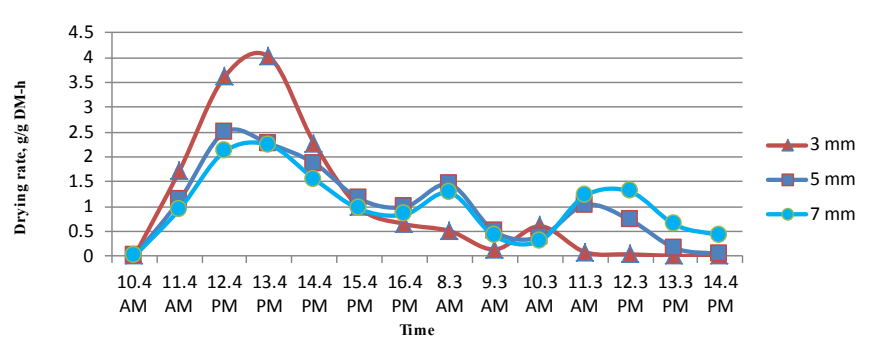

Figure 4: Variation in drying rate with time (Solar dried) 


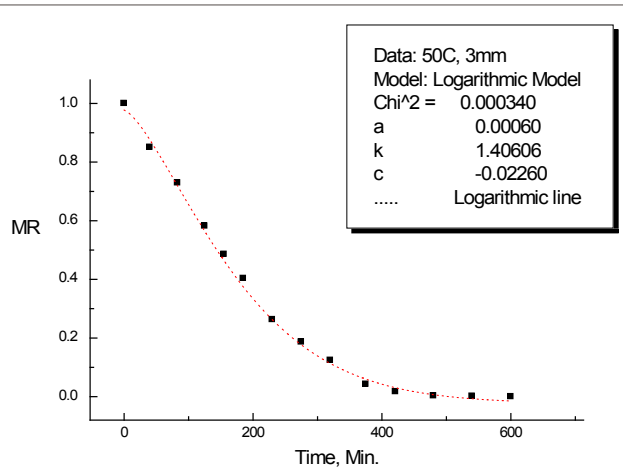

Figure 5: Variation in Moisture Ratio with drying time $\left(50^{\circ} \mathrm{C}, 3 \mathrm{~mm}\right.$ thickness $)$

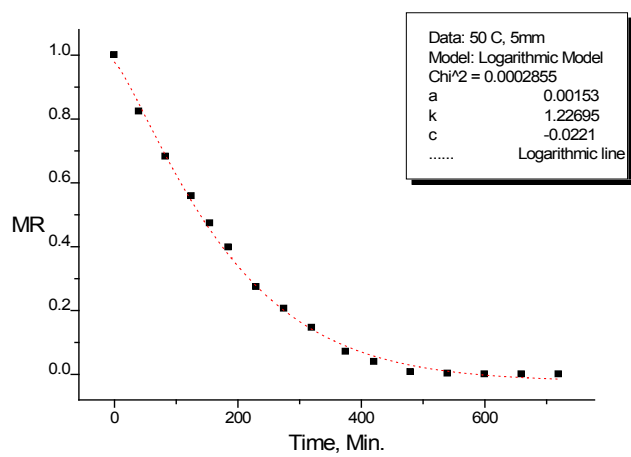

Figure 6: Variation in Moisture Ratio with drying time $\left(50^{\circ} \mathrm{C}, 5 \mathrm{~mm}\right.$ thickness $)$

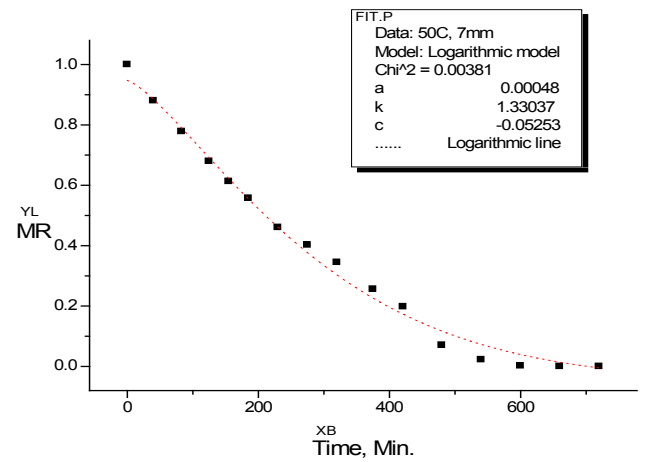

Figure 7: Variation in Moisture Ratio with drying time $\left(50^{\circ} \mathrm{C}, 7 \mathrm{~mm}\right.$ thickness $)$

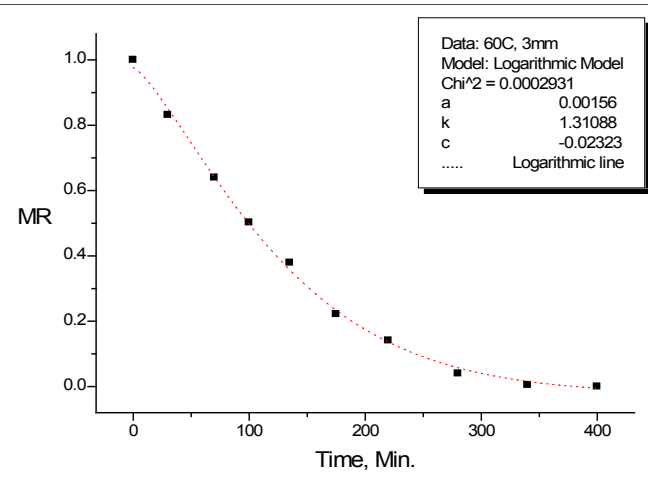

Figure 8: Variation in Moisture Ratio with drying time $\left(60^{\circ} \mathrm{C}, 3 \mathrm{~mm}\right.$ thickness $)$

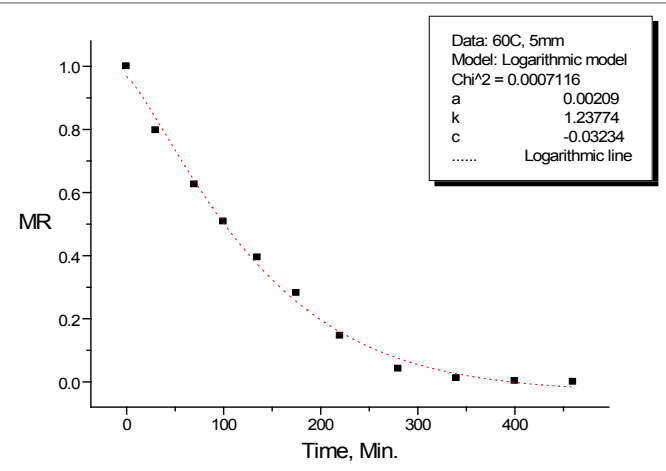

Figure 9: Variation in Moisture Ratio with drying time $\left(60^{\circ} \mathrm{C}, 5 \mathrm{~mm}\right.$ thickness $)$

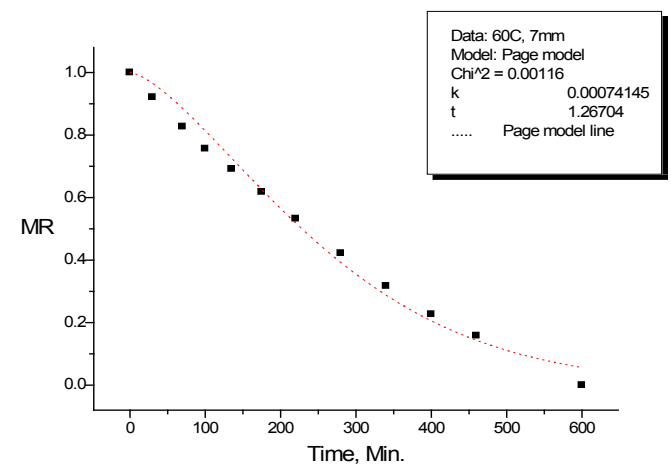

Figure 10: Variation in Moisture Ratio with drying time $\left(60^{\circ} \mathrm{C}, 7 \mathrm{~mm}\right.$ thickness $)$

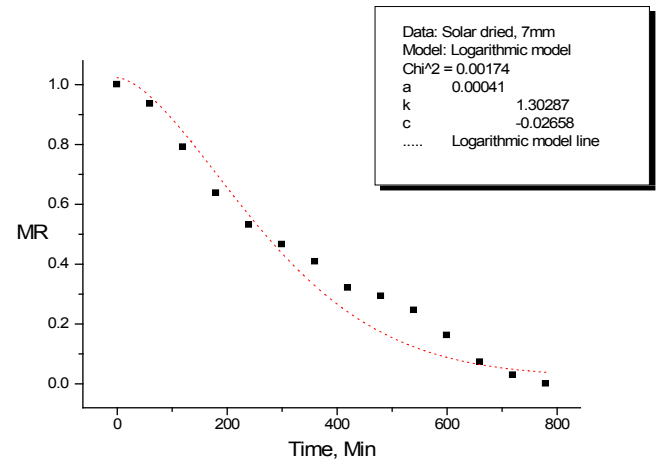

Figure 11: Variation in Moisture Ratio with time (Solar dried, $7 \mathrm{~mm}$ thickness)

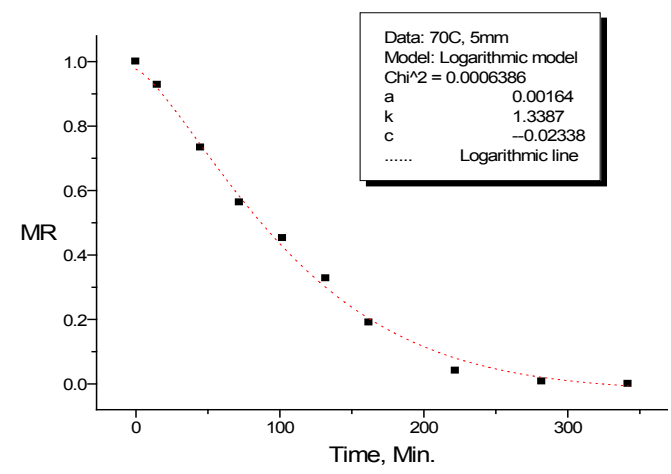

Figure 12: Variation in Moisture Ratio with drying time $\left(70^{\circ} \mathrm{C}, 5 \mathrm{~mm}\right.$ thickness $)$ 
Citation: Gojiya DK, Vyas DM (2015) Studies on Effect of Slice Thickness and Temperature on Drying Kinetics of Kothimbda (Cucumis Callosus) and its Storage. J Food Process Technol 6: 406. doi:10.4172/2157-7110.1000406

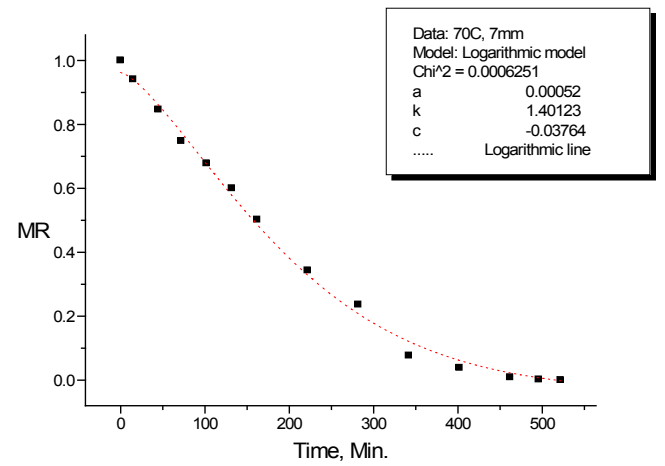

Figure 13: Variation in Moisture Ratio with drying time $\left(70^{\circ} \mathrm{C}, 7 \mathrm{~mm}\right.$ thickness $)$

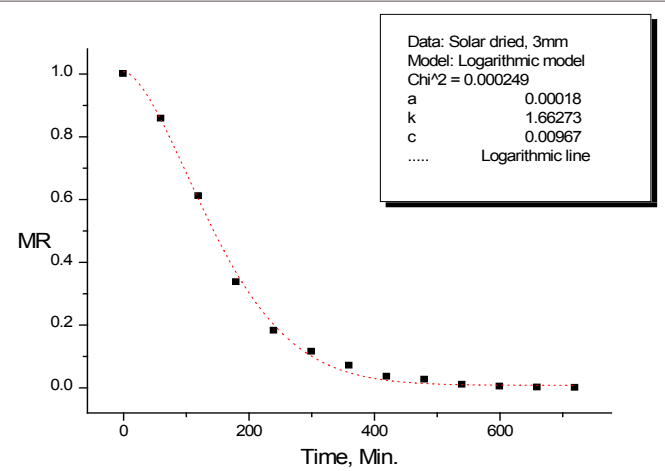

Figure 14: Variation in Moisture Ratio with time (Solar dried, 3mm thickness)

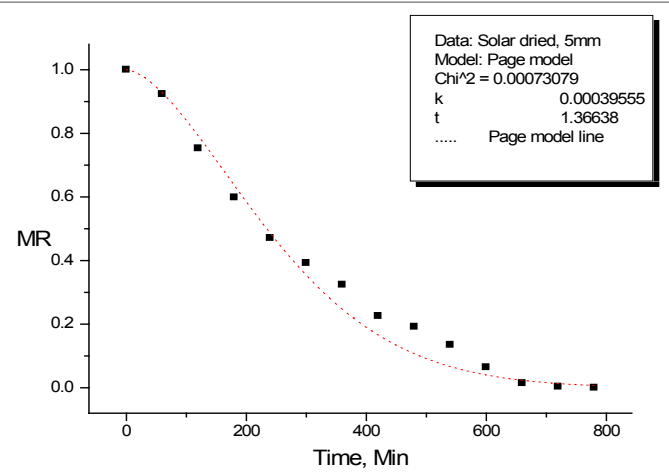

Figure 15: Variation in Moisture Ratio with time (Solar dried, $5 \mathrm{~mm}$ thickness)

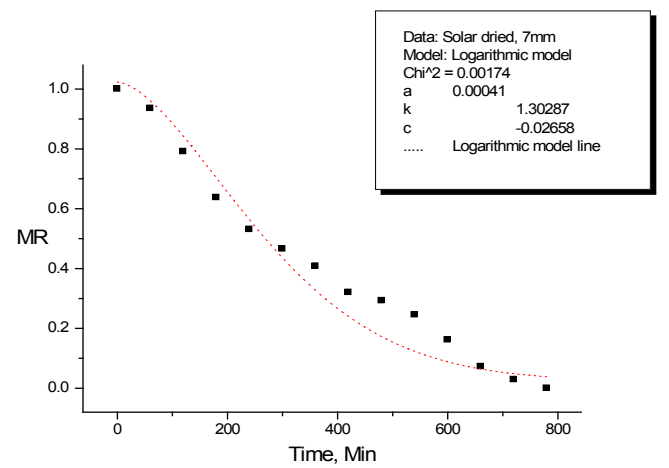

Figure 16: Variation in Moisture Ratio with time (Solar dried, $7 \mathrm{~mm}$ thickness)

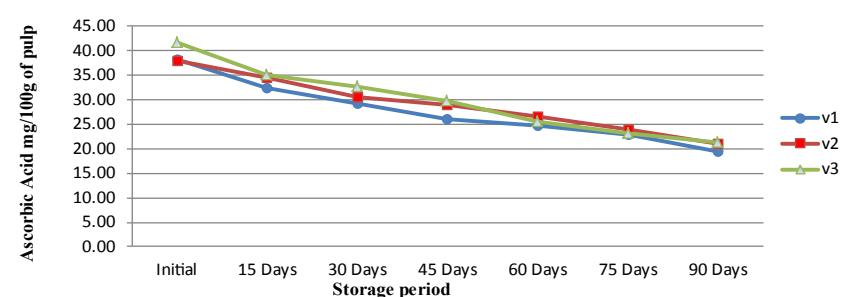

Figure 17: Effect of Thickness Levels on Ascorbic acid content of Kothimbda slice powder

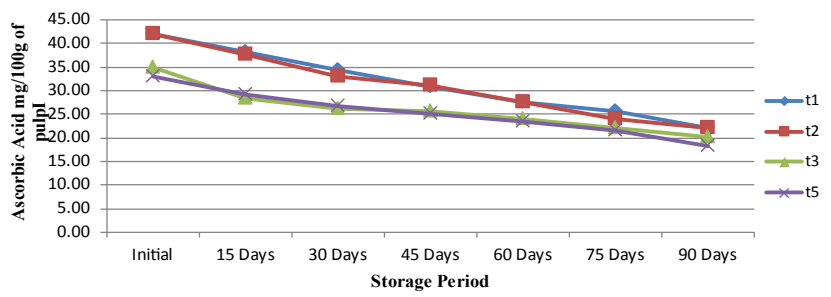

Figure 18: Effect of Temperature Levels on Ascorbic acid content of Kothimbda slice powder

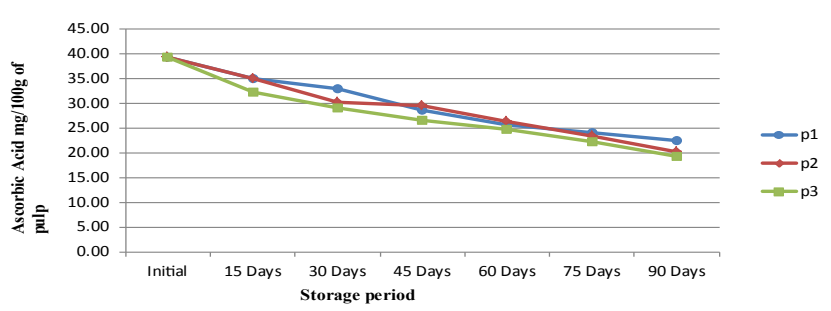

Figure 19: Effect of Packaging Materials on Ascorbic acid content of Kothimbda slice powder.

While, the lowest in the Solar dried samples of $5 \mathrm{~mm}$ thickness slices. As per the thickness of slice, the $7 \mathrm{~mm}$ thickness samples retained the highest ascorbic acid content while the lowest with $3 \mathrm{~mm}$ thickness samples. The $\mathrm{v}_{3} \mathrm{t}_{1}$ and $\mathrm{v}_{3} \mathrm{t}_{2}$ treatment combinations gave the highest ascorbic acid whereas $\mathrm{v}_{2} \mathrm{t}_{4}$, the lowest ascorbic acid content during drying of Kothimbda (Table 2). Higher value of C.V. might be due to highly potential significance of both temperature and thickness and their interaction. As the ascorbic acid is highly sensitive towards the temperature and rapidly degrade in the presence of heat, the samples with more thickness and dried with lower temperature, retain maximum ascorbic acid. Similar results are reported by Ramallo and Mascheroni [10] during drying of pineapple half slices, Marfil et al. [11] for tomatoes and Pendre et al. [12] in case of okra drying.

Effects of different packaging materials, temperature and slice thickness levels on ascorbic acid during storage

From Table 3 as well as from Figures 17-19, it was observed that the ascorbic acid content of the stored Kothimbda fruit powder was decreasing with the increase in storage period when stored at room temperature.

In case of Slice Thickness, for 3, 5 and $7 \mathrm{~mm}$ samples, the ascorbic acid content was varying from 38.33 to $19.44,37.91$ to 21.11 and 41.66 to $21.39 \mathrm{mg} / 100 \mathrm{~g}$ during 90 days of storage period at room temperature respectively. From these observations it is clear that the loss in ascorbic acid during storage was minimum in the powder made from $5 \mathrm{~mm}$ 
Citation: Gojiya DK, Vyas DM (2015) Studies on Effect of Slice Thickness and Temperature on Drying Kinetics of Kothimbda (Cucumis Callosus) and its Storage. J Food Process Technol 6: 406. doi:10.4172/2157-7110.1000406

Page 5 of 8

\begin{tabular}{|c|c|c|c|c|c|c|c|}
\hline \multicolumn{8}{|c|}{ Page Model, MR $=\exp \left(-k t^{n}\right)$} \\
\hline No. & Temp ${ }^{\circ} \mathrm{C}$ & Thickness, mm & $\mathbf{k}$ & $\mathbf{n}$ & COD, $R^{2}$ & $x^{2}$ & \\
\hline 1 & 50 & 3 & 0.00108 & 1.3011 & 0.99437 & 0.00072 & \\
\hline 2 & & 5 & 0.00146 & 1.24851 & 0.99636 & 0.00042 & \\
\hline 3 & & 7 & 0.00146 & 1.16225 & 0.98109 & 0.00227 & \\
\hline 4 & 60 & 3 & 0.00173 & 1.30629 & 0.99697 & 0.00044 & \\
\hline 5 & & 5 & 0.00287 & 1.19627 & 0.99278 & 0.00098 & \\
\hline 6 & & 7 & 0.00074 & 1.26704 & 0.98956 & 0.00116 & \\
\hline 7 & 70 & 3 & 0.00292 & 1.23202 & 0.99411 & 0.00087 & \\
\hline 8 & & 5 & 0.00186 & 1.32904 & 0.99543 & 0.00072 & \\
\hline 9 & & 7 & 0.00076 & 1.35518 & 0.99263 & 0.00112 & \\
\hline 10 & Solar drying & 3 & 0.00031 & 1.55111 & 0.9971 & 0.00039 & \\
\hline 11 & & 5 & 0.0004 & 1.36638 & 0.99421 & 0.00073 & \\
\hline 12 & & 7 & 0.00058 & 1.26225 & 0.98464 & 0.00176 & \\
\hline \multicolumn{8}{|c|}{ Henderson \& Pabis model, MR = a exp(-kt) } \\
\hline No. & Temp., ${ }^{\circ} \mathrm{C}$ & Thick., mm & $\mathbf{a}$ & $\mathbf{k}$ & COD, $\mathbf{R}^{2}$ & $x^{2}$ & \\
\hline 1 & 50 & 3 & 1.06734 & 0.00571 & 0.97381 & 0.00337 & \\
\hline 2 & & 5 & 1.05439 & 0.00574 & 0.98604 & 0.00161 & \\
\hline 3 & & 7 & 1.06141 & 0.00388 & 0.9682 & 0.00381 & \\
\hline 4 & 60 & 3 & 1.05321 & 0.00821 & 0.98359 & 0.00237 & \\
\hline 5 & & 5 & 1.02792 & 0.00778 & 0.985 & 0.00204 & \\
\hline 6 & & 7 & 1.04506 & 0.00344 & 0.97255 & 0.00306 & \\
\hline 7 & 70 & 3 & 1.02792 & 0.00778 & 0.985 & 0.00204 & \\
\hline 8 & & 5 & 1.04196 & 0.00926 & 0.9804 & 0.0031 & \\
\hline 9 & & 7 & 1.07233 & 0.00535 & 0.97144 & 0.00434 & \\
\hline 10 & Solar drying & 3 & 1.08155 & 0.00608 & 0.97049 & 0.00393 & \\
\hline 11 & & 5 & 1.07116 & 0.00359 & 0.97559 & 0.00308 & \\
\hline 12 & & 7 & 1.05043 & 0.00283 & 0.96891 & 0.00356 & \\
\hline \multicolumn{8}{|c|}{ Logarithmic Model, MR = a exp(-kt) +c } \\
\hline No. & Temp ${ }^{\circ} \mathrm{C}$ & Thick., mm & a & k & c & COD, $\mathbf{R}^{2}$ & $x^{2}$ \\
\hline 1 & 50 & 3 & 0.0006 & 1.40606 & -0.0226 & 0.99798 & 0.00083 \\
\hline 2 & & 5 & 0.00153 & 1.22055 & -0.0281 & 0.99761 & 0.0003 \\
\hline 3 & & 7 & 0.00048 & 1.33031 & -0.05244 & 0.99203 & 0.00381 \\
\hline 4 & 60 & 3 & 0.00156 & 1.31088 & -0.0232 & 0.99822 & 0.00029 \\
\hline 5 & & 5 & 0.00209 & 1.23733 & -0.03289 & 0.99535 & 0.00071 \\
\hline 6 & & 7 & 0.00102 & 1.17926 & -0.0454 & 0.98446 & 0.00192 \\
\hline 7 & 70 & 3 & 0.00233 & 1.25701 & -0.03181 & 0.99613 & 0.00065 \\
\hline 8 & & 5 & 0.00164 & 1.3387 & -0.02338 & 0.99647 & 0.00064 \\
\hline 9 & & 7 & 0.00052 & 1.40123 & -0.03764 & 0.99623 & 0.00063 \\
\hline 10 & Solar drying & 3 & 0.00018 & 1.66273 & 0.00967 & 0.9983 & 0.00025 \\
\hline 11 & & 5 & 0.00023 & 1.48031 & 0.01749 & 0.99007 & 0.00137 \\
\hline 12 & & 7 & 0.00041 & 1.30287 & -0.02658 & 0.9861 & 0.00174 \\
\hline
\end{tabular}

Table 1: Constants of drying models 


\begin{tabular}{|c|c|}
\hline Effect & Ascorbic acid \\
\hline \multicolumn{2}{|c|}{ A) Between drying Temperatures ( $t$ ) } \\
\hline $50^{\circ} \mathrm{C}\left(\mathrm{t}_{1}\right)$ & 42.03 \\
\hline $60{ }^{\circ} \mathrm{C}\left(\mathrm{t}_{2}\right)$ & 42.03 \\
\hline $70{ }^{\circ} \mathrm{C}\left(\mathrm{t}_{3}\right)$ & 34.81 \\
\hline Solar dried $\left(\mathrm{t}_{4}\right)$ & 32.96 \\
\hline S. Em \pm & 0.91 \\
\hline $\mathrm{CD}$ at $5 \%$ & $2.60^{\star *}$ \\
\hline \multicolumn{2}{|c|}{ B) Slice thickness (v) } \\
\hline $3 \mathrm{~mm}\left(\mathrm{v}_{1}\right)$ & 35.41 \\
\hline $5 \mathrm{~mm}\left(\mathrm{v}_{2}\right)$ & 38.47 \\
\hline $7 \mathrm{~mm}\left(\mathrm{v}_{3}\right)$ & 40.00 \\
\hline S. Em \pm & 0.79 \\
\hline$C D$ at $5 \%$ & $2.255^{\star \star}$ \\
\hline \multicolumn{2}{|c|}{ C) Interaction t X v } \\
\hline S. Em \pm & 1.57 \\
\hline $\mathrm{CD}$ at $5 \%$ & $4.51^{*}$ \\
\hline C.V.\% & 10.14 \\
\hline
\end{tabular}

Table 2: Effect of drying Temperature (t) and Slice thickness (v) on Ascorbic acid of Kothimbda fruit during drying

thick slices followed by 3 and $7 \mathrm{~mm}$ (Table 3$)$.

Similarly, for Drying Temperature at 50,60 and $70^{\circ} \mathrm{C}$ and Solar drying samples, the ascorbic acid content was varying from 43.33 to $22.03,42.22$ to $22.03,36.66$ to 20.18 and 35.00 to $18.33 \mathrm{mg} / 100 \mathrm{~g}$ during 90 days of storage period at room temperature respectively. The observations indicated that the loss in ascorbic acid during storage was Minimum in the powder made from the solar dried samples followed by 70,60 and $50^{\circ} \mathrm{C}$ (Table 3 ).

The ascorbic acid content of the sample packed in Glass bottle, HDPE bag and Aluminum Coated P.P. bag was varying from 39.30 to $22.50,39.30$ to 20.14 and 39.30 to $19.30 \mathrm{mg} / 100 \mathrm{~g}$ during 90 days of storage period at room temperature respectively. From these observations it was asserted that the loss in ascorbic acid during storage was minimum in the powder packed in Glass bottle followed by HDPE bag and Aluminum Coated P.P. bag (Table 3).

The statistical analysed data revealed that the Slice Thickness was giving highly significant results for the ascorbic acid content in $\mathrm{mg} / 100$ g during 30 days and 45 days of storage at room temperature. It gave also significant. The minimum loss was found in $5 \mathrm{~mm}$ slice $\left(\mathrm{v}_{2}\right)$, indicating that for ascorbic acid retention in $5 \mathrm{~mm}$ slice was superior to $\mathrm{v}_{3}(7 \mathrm{~mm})$ and $\mathrm{v}_{1}(3 \mathrm{~mm})$. As far as Drying Temperature, the minimum ascorbic acid content was ranged from 18.33 to $22.03 \mathrm{mg} / 100 \mathrm{~g}$ on $90^{\text {th }}$ day of storage, whereas the maximum ascorbic acid content varying from 35.00 to $43.33 \mathrm{mg} / 100 \mathrm{~g}$ on the initial day of storage when stored at room temperature.

The Kothimbda powder prepared from the samples dried at $50^{\circ} \mathrm{C}$ $\left(\mathrm{t}_{1}\right)$ gave highest value of ascorbic acid followed by $60^{\circ} \mathrm{C}\left(\mathrm{t}_{2}\right), 70^{\circ} \mathrm{C}$ $\left(t_{3}\right)$ and Solar dried $\left(t_{4}\right)$. The drying temperature was observed highly significant for ascorbic acid content $(\mathrm{mg} / 100 \mathrm{~g})$ for all the stages of three months of storage period.

While in case of Packaging Materials used for Kothimbda powder storage, the ascorbic acid content ranged from 19.30 to $22.50 \mathrm{mg} / 100$ $\mathrm{g}$, observed on $90^{\text {th }}$ day of storage at room temperature (Table 3 ). The Kothimbda powder packed in Glass bottle $\left(\mathrm{p}_{1}\right)$ showing highest value of ascorbic acid content retention after 90 days of storage followed by powder packed in HDPE bag $\left(\mathrm{p}_{2}\right)$ and powder packed in Aluminum Coated P.P. bag $\left(\mathrm{p}_{3}\right)$. Packaging Materials $(\mathrm{p})$ was giving highly significant results for the ascorbic acid content retention in $\mathrm{mg} / 100 \mathrm{~g}$ during 15 days, 30 days and 90 days. It also gave significant result for 45 days of storage, while for the other stages of storage period found non-significant. The Glass bottles provide high barrier that preserved most of the antioxidants and functional properties of the powder as compared to HDPE bag and Aluminum Coated P.P. bag resulted in to less loss in Ascorbic acid during storage. Similar results were reported by Burdurlu et al. [13] in storage of citrus juice concentrates, Babarinde and Fabunmi [14] for effective packaging materials to retain quality parameters and Seevaratnam et al. [15].

Interaction between Slice Thickness and Temperature ( $\mathrm{v}$ X t) was giving significant values for storage for $15^{\text {th }}, 30^{\text {th }}, 45$ th, $90^{\text {th }}$ days and it showed non-significant results for $60^{\text {th }}, 75^{\text {th }}$ day of storage. Interaction between Slice Thickness and Packaging Materials ( $\mathrm{v} \mathrm{X} \mathrm{p)}$ gave significantly higher results for the storage of $15^{\text {th }}, 30^{\text {th }}, 90^{\text {th }}$ days and showed non-significant for $60^{\text {th }}, 75^{\text {th }}$ and $90^{\text {th }}$ day of storage for the ascorbic acid content retention of Kothimbda Powder for overall storage period. While the interaction between Temperature and Packaging Materials $(t \times p)$ was giving non-significant results. However, the combination between Slice Thickness and Temperature and Packaging Materials ( $\mathrm{v} \times \mathrm{t} \times \mathrm{p}$ ) indicated the significant results for $75^{\text {th }}$ days storage and observed non-significant results for all other storage period.

\section{Conclusions}

All the drying runs carried out for thin layer drying of Kothimbda slices at different drying temperatures and thicknesses including solar drying, the falling rate drying phenomena was observed. During the initial hours of drying, the drying rate was higher and diminishing with the time of drying. The minimum average drying rate of $3.36 \mathrm{~g} / \mathrm{hr}$ was observed during $50^{\circ} \mathrm{C}$ with $3 \mathrm{~mm}$ thickness drying run, while the maximum average drying rate as $5.66 \mathrm{~g} / \mathrm{hr}$ at $70^{\circ} \mathrm{C}$ with $5 \mathrm{~mm}$ thickness. During 50 and $60^{\circ} \mathrm{C}$ drying treatment the drying rate $(\mathrm{g} / \mathrm{g} \mathrm{DM}-\mathrm{h})$ for $5 \mathrm{~mm}$ thickness slice sample was found maximum followed by 3 and $7 \mathrm{~mm}$. While for $70^{\circ} \mathrm{C}$ and solar drying treatment the drying rate $(\mathrm{g} / \mathrm{g}$ DM-h) of $3 \mathrm{~mm}$ slice sample was observed maximum followed by 5 and $7 \mathrm{~mm}$. The observations taken during all the drying treatments were fitted to Henderson and Pabis, Page and Logarithmic model. The values of coefficient of determination $\left(\mathrm{r}^{2}\right)$ for all the three models under all the treatments were found to be above 0.9 , suggesting good fit of the observations. Though, the value of $\mathrm{r}^{2}$ under the Logarithmic Model was more followed by page [16] and Henderson and Pabis, indicating the Logarithmic model more reliable for prediction and found best fitted. The drying temperature and slice thickness affected significantly on the ascorbic acid content during drying of Kothimbda slice. The maximum ascorbic acid content was found in the powder prepared from slices of 7 $\mathrm{mm}$ thickness and dried at $50^{\circ} \mathrm{C} / 60^{\circ} \mathrm{C}$ temperature $\left(\mathrm{v}^{3} \mathrm{t}^{1} / \mathrm{v}^{3} \mathrm{t}^{2}\right.$ treatment) followed by powder prepared from slices of $5 \mathrm{~mm}$ thickness and dried at $50^{\circ} \mathrm{C} / 60^{\circ} \mathrm{C}$ temperature $\left(\mathrm{v}^{2} \mathrm{t}^{1} / \mathrm{v}^{2} \mathrm{t}^{2}\right.$ treatment). While, the lowest in the Solar dried samples of $5 \mathrm{~mm}$ thickness slices $\left(\mathrm{v}^{2} \mathrm{t}^{4}\right.$ treatment). As per 
Citation: Gojiya DK, Vyas DM (2015) Studies on Effect of Slice Thickness and Temperature on Drying Kinetics of Kothimbda (Cucumis Callosus) and its Storage. J Food Process Technol 6: 406. doi:10.4172/2157-7110.1000406

Page 7 of 8

\begin{tabular}{|c|c|c|c|c|c|c|c|}
\hline \multirow{3}{*}{ Treatment } & \multicolumn{7}{|c|}{ Ascorbic Acid (mg/100g) } \\
\hline & \multicolumn{7}{|c|}{ Storage Period in Days } \\
\hline & Initial & 15 & 30 & 45 & 60 & 75 & 90 \\
\hline \multicolumn{8}{|c|}{ Slice Thickness (v) } \\
\hline$v_{1}$ & 38.33 & 32.50 & 29.30 & 25.97 & 24.72 & 22.78 & 19.44 \\
\hline$v_{2}$ & 37.91 & 34.58 & 28.33 & 29.02 & 26.53 & 24.03 & 21.11 \\
\hline $\mathrm{v}_{3}$ & 41.66 & 35.14 & 32.64 & 29.72 & 25.55 & 23.19 & 21.39 \\
\hline S. Em. \pm & 0.54 & 0.66 & 0.86 & 0.75 & 0.71 & 0.60 & 0.65 \\
\hline CD (0.05) & $2.255^{\star \star}$ & $1.897^{*}$ & $2.478^{\star *}$ & $2.159^{* *}$ & NS & NS & NS \\
\hline \multicolumn{8}{|c|}{ Temperature $(t)$} \\
\hline $\mathrm{t}_{1}$ & 43.33 & 38.14 & 34.44 & 30.92 & 27.59 & 25.74 & 22.03 \\
\hline$t_{2}$ & 42.22 & 37.59 & 32.96 & 31.11 & 27.59 & 24.07 & 22.03 \\
\hline$t_{3}$ & 36.66 & 31.29 & 29.07 & 25.74 & 23.89 & 22.03 & 20.18 \\
\hline$t_{4}$ & 35.00 & 29.26 & 26.85 & 25.18 & 23.33 & 21.48 & 18.33 \\
\hline S. Em. \pm & 0.62 & 0.76 & 1.00 & 0.87 & 0.82 & 0.69 & 0.75 \\
\hline CD (0.05) & $1.78^{\star *}$ & $2.191^{* *}$ & $2.862^{\star *}$ & $2.493^{\star *}$ & $2.362^{\star *}$ & $1.98^{\star *}$ & $2.159^{\star \star}$ \\
\hline \multicolumn{8}{|c|}{ Packaging Material (p) } \\
\hline $\mathrm{p}_{1}$ & 39.30 & 35.00 & 33.05 & 28.61 & 25.69 & 24.16 & 22.50 \\
\hline $\mathrm{p}_{2}$ & 39.30 & 35.00 & 30.27 & 29.44 & 26.39 & 23.47 & 20.14 \\
\hline $\mathrm{p}_{3}$ & 39.30 & 32.21 & 29.16 & 26.66 & 24.72 & 22.36 & 19.30 \\
\hline S. Em. \pm & 0.54 & 0.66 & 0.86 & 0.75 & 0.71 & 0.60 & 0.65 \\
\hline CD (0.05) & NS & $1.897^{\star *}$ & $2.4789^{* *}$ & $2.159^{*}$ & NS & NS & $1.86^{* *}$ \\
\hline \multicolumn{8}{|c|}{ Interaction } \\
\hline \multicolumn{8}{|c|}{$\mathbf{v} \times \mathbf{t}$} \\
\hline S. Em. \pm & 1.07 & 1.32 & 1.73 & 1.50 & 1.43 & 1.20 & 1.30 \\
\hline CD (0.05) & $3.09^{*}$ & $3.79^{*}$ & $4.957^{* *}$ & $4.318^{* *}$ & NS & $3.44^{* *}$ & $3.73^{*}$ \\
\hline \multicolumn{8}{|c|}{$\mathbf{v X p}$} \\
\hline S. Em. \pm & 0.93 & 1.15 & 1.50 & 1.30 & 1.23 & 1.04 & 1.13 \\
\hline CD (0.05) & NS & $3.28^{\star *}$ & $4.3^{* *}$ & NS & NS & NS & $3.23^{*}$ \\
\hline \multicolumn{8}{|c|}{$t X p$} \\
\hline S. Em. \pm & 1.08 & 1.32 & 1.73 & 1.50 & 1.43 & 1.20 & 1.30 \\
\hline CD (0.05) & NS & NS & NS & NS & NS & NS & NS \\
\hline \multicolumn{8}{|c|}{$v \times t \times p$} \\
\hline S. Em. \pm & 1.86 & 2.29 & 2.99 & 2.61 & 2.47 & 2.08 & 2.26 \\
\hline$C D(0.05)$ & NS & NS & NS & NS & NS & $5.97^{*}$ & NS \\
\hline C. V. \% & 6.70 & 9.51 & 14.06 & 13.05 & 13.64 & 12.59 & 15.46 \\
\hline
\end{tabular}

Table 3: Effect of different Thicknesses, Temperature and Packaging Materials on Ascorbic acid content (mg/100g) of Kothimbda fruit powder during storage

the thickness of slice, the $7 \mathrm{~mm}$ thickness samples consisted the highest ascorbic acid content while the lowest with $3 \mathrm{~mm}$ thickness samples.

As the storage period increased from 0 to $90^{\text {th }}$ day, the ascorbic acid content of Kothimbda powder decrease for all the treatment. The loss in ascorbic acid during storage was minimum in the powder made from $5 \mathrm{~mm}$ thick slices followed by 3 and $7 \mathrm{~mm}$. The loss in ascorbic acid during storage was minimum in the powder made from the solar dried samples followed by 70,60 and $50^{\circ} \mathrm{C}$. The loss in ascorbic acid during storage was minimum in the powder packed in Glass bottle followed by HDPE bag and Aluminum Coated P.P. bag. Considering consolidated effects of each parameter studied and their interaction it was concluded that, To get good quality of Kothimbda powder and effective drying of Kothimbda slice, the Kothimbda slice of $5 \mathrm{~mm}$ thickness should be dried at $60^{\circ} \mathrm{C}$ air temperature with air velocity of $1.5 \mathrm{~m} / \mathrm{sec}$. To minimize the loss in ascorbic acid content of Kothimbda powder (16
Mesh) during storage for 90 days at room temperature, it should be packed in Glass bottle.

\section{Acknoledgement}

I have unique privilege and pleasure to express my deep sense of gratitude and sincere thanks to my affectionate teacher and honorable Major Advisor, Prof. D. M. Vyas.

\section{References}

1. Singh M, Joshi R (2010) Famine Food of Arid Rajasthan: Utilization, Perceptions and Need to Integrate Social Practices by Bio-Resolutions. Journal of Ethnobiology and Ethnomedicine 4: 121-124.

2. Goyal M, Sharma SK (2009) Traditional Knowledge and Value Addition Prospects of Desert Region of North West India. Indian Journal of Traditional Knowledge 8: 581-585.

3. Onayemi O (1981) Post-harvest food loss management in Nigeria. Industry and Environment 4: 5-8. 
Citation: Gojiya DK, Vyas DM (2015) Studies on Effect of Slice Thickness and Temperature on Drying Kinetics of Kothimbda (Cucumis Callosus) and its Storage. J Food Process Technol 6: 406. doi:10.4172/2157-7110.1000406

4. Sadasivam S, Manikam A (1992) Biochemical methods of agricultural science. New Delhi, Wiley Eastern Ltd.

5. Kabiru AA, Joshua AA, Raji AO (2013) Effect of slice thickness and temperature on the drying kinetics of Mango (Mangifera Indica). International Journal of Research and Reviews in Applied Sciences 15: 41-50.

6. Islam MS, Haque MA, Islam MN (2012) Effects of drying parameters on dehydration of Green Banana (Musa sepientum) and its use in Potato (Solanum tuberosum) chips formulation. A Scientific Journal of Krishi Foundation 10: 87-97.

7. Limpaiboon $\mathrm{K}$ (2011) Effects of temperature and slice thickness on drying kinetics of Pumpkin slices. Walailak Journal of Science and Technology 8: 159-166.

8. Abano EE, Ma H, Qu W (2011) Influence of air temperature on the drying kinetics and quality of Tomato slices. Journal Food Processing \& Technology 2: $1-9$.

9. Henderson SM, Pabis S (1991) Grain drying theory I. Temperature effect on drying coefficient. Journal of Agriculture Engineering Research 6: 169-174.

10. Ramallo AL, Mascheroni RH (2004) Prediction and determination of Ascorbic Acid content during Pineapple drying. In: Drying 2004 - Proceedings of the 14th International Drying Symposium (IDS 2004). Sao Paulo, Brazil.
11. Marfil PHM, Santos EM, Telis VRN (2008) Ascorbic acid degradation kinetics in tomatoes at different drying conditions. LWT Food Science and Technology 41: 1642-1647.

12. Pendre NK, Nema PK, Sharma HP, Rathore SS, Kushwah SS (2012) Effect of drying temperature and slice size on quality of dried okra (Abelmoschus esculentus (L.) Moench). Journal of Food Science and Technology 49: 378-381.

13. Burdurlu HS, Koca N, Karadeniz F (2006) Degradation of vitamin C in citrus juice concentrates during storage. Journal of Food Engineering 74: 211-216.

14. Babarinde GO, Fabunmi OA (2009) Effects of packaging materials and storage temperature on quality of fresh Okra (Abelmoschus Esculentus) fruit. Agriculture Tropica \& Subtropica 42:151-156.

15. Seevaratnam V, Banumathi $P$, Premalatha MR, Sundaram SP Arumugam $T$ (2012) Effect of packaging materials on retention of quality characteristics of selected dehydrated green leafy vegetables during storage. World Journal of Dairy \& Food Sciences 7: 190-194.

16. Page GE (1949) Factors influencing the maximum rate of air drying shelled corn in thin layers. MS Thesis (Unpublished). Purdue University, West Lafayette, IN. 